\title{
Pengembangan Alat Permainan Edukatif Busy Bag untuk Kemampuan Motorik Halus Anak Usia 3-4 tahun
}

\author{
Elis Safitri, Usep Kustiawan*, Suryadi \\ Universitas Negeri Malang, Jl. Semarang No. 5 Malang, Jawa Timur, Indonesia \\ *Penulis korespondensi, Surel: usep.kustiawan@fip.um.ac.id.
}

Paper received: 1-4-2021; revised: 22-4-2021; accepted: 29-4-2021

\begin{abstract}
The background of this research and development is the underutilization of learning facilities and infrastructure such as game media. The aim of this research and development is to produce busy bag educational toys for fine motor skills of children aged 3-4 years. The research methods used through the Borg and Gall procedures are selected and adjusted to field conditions through 6 steps. Based on formative testing for early childhood material experts obtained a percentage of 92,5 percent, early childhood game experts obtained a percentage of 85 percent. From small group trials the percentage of user data was obtained 95,3 percent, 96 percent convenience, 92 percent attractiveness, 98 percent security. The result showed that this busy bag educational game is very easy, interesting, and safe so it is suitable to be used to stimulate fine motor skills of children aged 3-4 years.
\end{abstract}

Keywords: fine motor skills; busy bag educational toys; children aged 3-4 years

\begin{abstract}
Abstrak
Latar belakang penelitian dan pengembangan ini adalah kurang dimanfaatkannya sarana dan prasarana pembelajaran seperti media permainan. Tujuan dari penelitian dan pengembangan ini adalah untuk menghasilkan alat permainan edukatif busy bag untuk kemampuan motorik halus anak usia 3-4 tahun. Metode penelitian yang digunakan melalui prosedur Borg and Gall yang dipilih dan disesuaikan dengan kondisi di lapangan melalui 6 langkah. Berdasarkan uji formatif kepada ahli materi anak usia dini diperoleh persentase 92,5 persen, ahli permainan anak usia dini diperoleh persentase 85 persen. Dari hasil uji coba kelompok kecil diperoleh data pengguna 95,3 persen, kemudahan 96 persen, kemenarikan 92 persen, keamanan 98 persen. Hasil penelitian menunjukkan bahwa alat permainan edukatif busy bag ini sangat mudah, menarik, dan aman sehingga layak digunakan untuk menstimulasi kemampuan motorik halus anak usia 3-4 tahun.
\end{abstract}

Kata kunci: kemampuan motorik halus; alat permainan edukatif busy bag; anak usia 3-4 tahun

\section{Pendahuluan}

Bermain merupakan kegiatan yang digemari anak, melalui kegiatan bermain anak akan senang dan tidak merasa terbebani dengan materi pembelajaran yang yang telah disediakan oleh guru. Kunci utama dalam proses pendidikan anak usia dini yakni membuat anak nyaman dengan segala aktifitas yang diperuntukkan untuk anak. Pernyataan tersebut sejalan dengan Rasyid dalam (Ningsih, 2018) menyatakan bahwa ketika berinteraksi dengan anak ciptakan suasana yang menyenangkan dan penuh perhatian, proses pendidikan anak usia dini harus berada dalam lingkungan yang nyaman dan menyenangkan sesuai kebutuhan anak.

Salah satu cara menciptakan suasana nyaman dan menyenangkan dalam pembelajaran adalah dengan bermain. Dalam melakukan aktivitas tersebut anak tentunya membutuhkan media yang dapat menarik minat belajar anak. (Iffah, 2018) menyatakan bahwa alat permainan edukatif merupakan alat permainan yang digunakan untuk belajar. Alat ini digunakan dalam 
proses belajar dalam bentuk permainan, sehingga murid tertarik dan terangsang pikiran dan perasaannya pada kegiatan belajar untuk mencapai tujuan pembelajaran.

Perkembangan motorik merupakan salah satu faktor yang sangat penting dalam perkembangan anak secara keseluruhan. Kemampuan motorik halus anak prasekolah perlu distimulasi dan dilatih sejak dini agar gerakan yang dihasilkan dapat berkembang secara optimal. (Decaprio, 2013) menyatakan stimulasi yang diberikan kepada anak membutuhkan kesabaran dan menggunakan cara yang berbeda-beda setiap anak. Pemberian stimulus sedikit banyak dipengaruhi oleh lingkungan, lingkungan tersebut adalah lingkungan keluarga dan sekolah.

Dalam kegiatan belajar tentang keterampilan motorik halus dibutuhkan media tertentu untuk meningkatkan motivasi dan menarik minat anak dalam belajar. Untuk itu diperlukan sumber belajar yang dapat membantu guru dalam mengajar dan melatih perkembangan keterampilan motorik. Akan tetapi, guru jarang memanfaatkan penggunaan media secara maksimal.

Berdasarkan hasil observasi dan wawancara terhadap kepala sekolah dan guru pada tiga lembaga KB di Kota Malang dapat ditemukan bahwa proses pembelajaran di kelas secara umum berupa kegiatan yang dilakukan pada kemampuan motorik halus anak usia 3-4 tahun masih sering menggunakan Lembar Kerja Anak (LKA), pembelajaran yang dilakukan di kelas masih mengutamakan keterampilan menulis dan menggambar sehingga kurangnya stimulasi gerakan otot-otot halus dalam mengkoordinasikan otot mata, tangan dan jari-jemari.

Faktor penyebab masalah dari ketiga lembaga KB yang terdapat di Kota Malang tersebut adalah 1) kesulitan guru dalam mempersiapkan media, 2) media yang ada kurang menarik, 3) sarana dan prasarana yang kurang lengkap, 4) guru cenderung memberikan tugas dengan menggunakan lembar kerja sehingga stimulasi motorik halus kurang optimal.

Adanya permasalahan tersebut, peneliti memberikan solusi dengan menciptakan sebuah produk berupa alat permainan edukatif busy bag yang dapat digunakan sebagai inovasi media pembelajaran untuk kemampuan motorik halus anak terutama dalam mengkoordinasikan otot mata, tangan, dan jari jemari.

\section{Metode}

Penelitian ini merupakan jenis penelitian dan pengembangan R\&D (Research and Development) yang berorientasi pada pengembangan produk. (Sukmadinata, 2009) menyebutkan bahwa penelitian dan pengembangan adalah suatu proses atau langkah-langkah untuk mengembangkan suatu produk baru atau menyempurnakan produk yang ada dan dapat dipertanggungjawabkan.

Pelaksanaan penelitian dan pengembangan ini menghasilkan suatu produk berupa aktivitas belajar motorik halus menggunakan alat permainan, produk yang dihasilkan berupa alat permainan edukatif busy bag untuk menstimulasi kemampuan motorik halus anak usia 34 tahun yang tervalidasi. Penelitian dan pengembangan ini dirancang untuk untuk mendapatkan data mengenai keamanan, kemenarikan, kemudahan dalam menggunakan alat permainan edukatif busy bag. Produk yang dihasilkan sudah tervalidasi dan dinyatakan layak untuk digunakan oleh para ahli dibidangnya. 
Peneliti mengacu pada pedoman penelitian dan pengembangan Borg \& Gall dalam (Sugiyono, 2016) langkah-langkah umum yang diterapkan ada sepuluh langkah penelitian dan pengembangan, akan tetapi sepuluh langkah tersebut bukan suatu langkah yang baku dalam penelitian. Pengambilan langkah ini didukung pendapat dari (Hasyim, 2016) bahwa langkahlangkah R\&D dapat disederhanakan dan disesuaikan dengan kebutuhan penelitian. Keterbatasan pada aspek waktu dan pelaksanaan penelitian serta hingga langkah ke 6 sudah cukup untuk menguji kevalidan dan kelayakan suatu produk yang dikembangkan.

Prosedur penelitian dan pengembangan memaparkan langkah-langkah prosedural yang dilakukan oleh peneliti yaitu: 1) Potensi dan masalah didasarkan hasil analisis kebutuhan yang dilakukan oleh peneliti pada tiga lembaga di Kota Malang. Potensi dan masalah yang didapat adalah kurangnya inovasi dalam proses pembelajaran terlihat dari kurangnya minat anak dalam proses belajar. 2) Melakukan penelitian dan pengumpulan data dengan tujuan mengumpulkan informasi mengenai kebutuhan dan permasalahan yang sedang dihadapi di kelas yang dilakukan dengan cara wawancara kepada guru dan observasi kegiatan pembelajaran. 3) Melakukan perencanaan berupa penyusunan rancangan produk dengan cara mengembangkan produk alat permainan edukatif busy bag yang sesuai dengan indikator motorik halus anak usia 3-4 tahun. 4) Melakukan validasi kepada para ahli yaitu ahli materi dan ahli permainan untuk menilai dan memberikan masukan-masukan baik dari segi kelebihan maupun kelemahan produk. 5) Revisi produk setelah melakukan validasi dari beberapa ahli, setelah produk direvisi dikatakan valid maka dilakukan tahap selanjutnya uji coba produk. 6) Melakukan uji coba awal (uji coba kelompok kecil) dengan jumlah sampel 10 anak usia 3-4 tahun. Uji coba ini bertujuan untuk melihat keefektivitasan produk yang akan dikembangkan.

Subjek yang dilibatkan dalam pengambilan data penelitian pengembangan alat permainan edukatif busy bag adalah pengumpulan informasi dilakukan dengan cara pengamatan pembelajaran terkait media pembelajaran di KB Madani 2, Pos PAUD Tunas Cendekia, dan KB Negeri Pembina 5 Kota Malang. Subjek uji coba ahli terdiri dari dua ahli materi anak usia dini, dan dua ahli permainan anak usia dini. Subjek uji coba kelompok kecil terdiri dari sepuluh anak usia 3-4 tahun di Desa Wotan Kecamatan Panceng Kabupaten Gresik.

Jenis data yang digunakan dalam penelitian ini adalah bersifat kualitatif dan kuantitatif. Data kualitatif diperoleh dari wawancara terhadap guru sebagai data awal analisis kebutuhan dan hasil tinjauan para ahli berupa saran dan masukan mengenai alat permainan yang akan dikembangkan. Data kuantitatif diperoleh dari hasil perhitungan lembar angket yang diisi oleh para ahli dan hasil pengisian lembar observasi saat uji coba kelompok kecil dalam menggunakan alat permainan edukatif busy bag terkait dengan aspek kemudahan, keamanan dan kemenarikan.

Instrumen yang digunakan pada penelitian pengembangan ini adalah dengan wawancara, angket, lembar observasi, dan dokumentasi. Wawancara digunakan untuk memperoleh data awal mengenai motorik halus. Sedangkan angket, lembar observasi dan dokumentasi digunakan untuk mengumpulkan data hasil review dari ahli media, ahli materi, serta subjek penelitian pada saat uji coba lapangan. Adapun kisi-kisi penilaian dari instrumen validasi ahli materi anak usia dini, disajikan pada tabel sebagai berikut. 
Tabel 1. Tabel kriteria kelayakan produk

\begin{tabular}{cll}
\hline No. & Kriteria & Tingkat Validitas \\
\hline 1 & $81 \%-$ & Sangat valid, sangat efektif, sangat tuntas, dapat digunakan tanpa \\
& $100 \%$ & perbaikan. \\
\hline 2 & $61 \%-$ & Cukup valid, cukup efektif, cukup tuntas, dapat digunakan namun \\
& $80 \%$ & perlu perbaikan kecil. \\
\hline 3 & $41 \%-$ & Kurang valid, kurang efektif, atau kurang tuntas, perlu perbaikan \\
& $60 \%$ & besar, disarankan tidak dipergunakan. \\
\hline 4 & $21 \%-$ & Tidak valid, tidak efektif, tidak tuntas, tidak bisa digunakan. \\
& $40 \%$ & \\
\hline 5 & $00 \%-$ & Sangat tidak valid, sangat tidak efektif, sangat tidak tuntas, tidak bisa \\
& $20 \%$ & digunakan. \\
\hline
\end{tabular}

Sumber: (Akbar, 2013).

\section{Hasil dan Pembahasan}

Berdasarkan pengumpulan data yang diperoleh dari hasil validasi kepada empat ahli, yakni dua ahli materi anak usia dini dan dua ahli permainan anak usia dini. Dan data hasil uji coba kelompok kecil yang dilakukan pada anak usia 3-4 tahun dengan sampel 10.

\subsection{Hasil Analisis Data Tinjauan Ahli Materi}

Validasi ahli materi diperoleh dari 2 Dosen PGPAUD yang diberikan angket dengan jumah pertanyaan sebanyak 10 soal. Data hasil validasi menurut ahli materi anak usia dini diperoleh hasil sebagai berikut;

Tabel 2. Keseluruhan Data Hasil Validasi Ahli Materi Anak Usia Dini

\begin{tabular}{lll}
\hline No. & Ahli Materi & Presentase \\
\hline 1. & Ahli materi 1 & $90 \%$ \\
\hline 2. & Ahli materi 2 & $95 \%$ \\
\hline Rata-rata & $92,5 \%$ \\
\hline
\end{tabular}

Berdasarkan validasi terkait dengan materi dalam alat permainan busy bag, ahli materi pertama menilai $90 \%$ dan ahli materi kedua menilai $95 \%$. Hasil persentase tersebut apabila diambil rata-rata akan didapatkan hasil sebesar 92,5\%, maka dapat disimpulkan bahwa ahli materi sangat setuju dengan produk alat permainan edukatif busy bag terkait aspek kemudahan, kemenarikan dan keamanan. Apabila persentase tersebut dikaitkan dengan tingkat kriteria kelayakan produk menurut (Akbar, 2013) kelayakan produk yang dikembangkan mencapai tingkat persentase $81 \%$ - 100\%, maka alat permainan edukatif busy bag tergolong kategori sangat valid.

Hasil revisi dari ahli materi yaitu warna kantong tempat penyimpanan alat meronce diganti dengan warna yang lebih cerah, magnet untuk memancing gunakan yang daya rekatnya lebih kuat, cover tas APE diberi hiasan atau pemilihan warna huruf dibuat lebih menarik, tambahkah satu kegiatan yang menantang untuk dilakukan anak usia 4 tahun sehingga anak tidak mudah bosan. 


\subsection{Hasil Analisis Data Tinjauan Ahli Permainan}

Validasi ahli permainan diperoleh dari 2 Dosen PGPAUD yang diberikan angket dengan jumah pertanyaan sebanyak 10 soal. Data hasil validasi menurut ahli permainan anak usia dini diperoleh hasil sebagai berikut;

Tabel 3. Keseluruhan Data Hasil Validasi Ahli Permainan Anak Usia Dini

\begin{tabular}{lll}
\hline No. & Ahli Materi & Presentase \\
\hline 1. & Ahli permainan 1 & $77,5 \%$ \\
\hline 2. & Ahli permainan 2 & $92,5 \%$ \\
\hline Rata-rata & $85 \%$ \\
\hline
\end{tabular}

Berdasarkan validasi terkait dengan alat permainan busy bag, didapatkan hasil validasi ahli permainan pertama sebesar $77,5 \%$ dan ahli permainan kedua sebesar $92,5 \%$. Hasil persentase tersebut apabila diambil rata-rata akan didapatkan hasil sebesar 85\%, sehingga dapat disimpulkan bahwa ahli permainan sangat setuju dengan produk alat permainan edukatif busy bag terkait aspek kemudahan, kemenarikan dan keamanan. Apabila dikaitkan dengan tingkat kriteria kelayakan produk menurut (Akbar, 2013) kelayakan produk yang dikembangkan mencapai tingkat persentase $81 \%$ - 100\%, maka alat permainan edukatif busy bag tergolong kategori sangat valid.

Hasil revisi dari ahli permainan yaitu, pilih resleting yang mudah dioperasikan, beri sedikit aksen warna hitam pada tubuh ikan paus agar lebih menarik, semburan air dari ikan paus sebaiknya dibuat warna putih agar terlihat, kancing penutup kantong ronce dibuat presisi agar dapat dikancingkan dengan sempurna, pemilihan bahan pita harus yang awet, variasikan beberapa kegiatan yang dapat meningkatkan motorik halus anak dan menarik minat anak.

\subsection{Hasil Analisis Data Uji Coba Kelompok Kecil}

Hasil uji coba kelompok kecil tentang produk pengembangan alat permainan edukatif busy bag untuk kemampuan motorik halus anak usia 3-4 tahun dilakukan terhadap sepuluh anak usia 3-4 tahun di Desa Wotan. Secara keseluruhan dari data hasil uji coba kelompok kecil terkait aspek kemudahan, kemenarikan, dan keamanan diperoleh rata-rata sebagai berikut:

Tabel 4. Keseluruhan Data Uji Coba Kelompok Kecil

\begin{tabular}{lll}
\hline No. & \multicolumn{1}{c}{ Ahli Validasi } & Persentase \\
\hline 1. & Aspek Kemudahan & $96 \%$ \\
\hline 2. & Aspek Kemenarikan & $92 \%$ \\
\hline 3. & Aspek Keamanan & $98 \%$ \\
\hline Rata-rata & $95,3 \%$ \\
\hline
\end{tabular}

Hasil analisis data uji coba kelompok kecil dalam pengembangan alat permainan edukatif busy bag untuk kemampuan motorik halus anak usia 3-4 tahun dengan menggunakan sepuluh subjek terkait dengan aspek kemudahan diperoleh persentase sebesar $96 \%$ alat permainan edukatif busy bag mudah dilakukan anak, terkait aspek kemenarikan diperoleh persentase sebesar 92\% alat permainan edukatif busy bag menarik untuk anak dan terkait dengan aspek keamanan diperoleh persentase sebesar $98 \%$ alat permainan edukatif busy bag 
aman digunakan anak. Dari uraian tersebut, hasil uji coba kelompok kecil diperoleh rata-rata keseluruhan dengan persentase 95,3\% sehingga alat permainan edukatif busy bag dapat digunakan untuk kemampuan motorik halus anak usia 3-4 tahun. Apabila dikaitkan dengan tingkat kriteria kelayakan produk menurut (Akbar, 2013) kelayakan produk yang dikembangkan mencapai tingkat persentase 81\% - 100\%, maka alat permainan edukatif busy bag tergolong kategori sangat valid.

Hasil penelitian dan pengembangan menunjukkan bahwa alat permainan edukatif busy bag sangat layak dan sangat valid digunakan untuk melatih kemampuan motorik halus anak terutama dalam mengkoordinasikan otot tangan, mata, dan jari-jemari. Hal ini dibuktikan dari hasil validasi dua ahli materi dengan persentase $92,5 \%$ hasil validasi dua ahli permainan sebesar 85\%, dan hasil uji coba kelompok kecil dengan subjek sebanyak 10 anak usia 3-4 tahun di Desa Wotan mendapat persentase 95,3\%. Hal tersebut sejalan dengan pernyataan (Iffah, 2018) bahwa pengembangan alat permainan edukatif sangat tepat dijadikan sebagai media untuk mengembangkan motorik anak, karena karakteristik pengajaran di TK adalah bermain sambil belajar atau belajar sambil bermain. (Decaprio, 2013) menyatakan bahwa perkembangan motorik halus berperan dalam menunjang keterampilan anak dalam menunjang keterampilan anak dalam berbagai hal. Selain itu dapat mendorong sikap mandiri anak sehingga anak mampu menyelesaikan tugasnya tanpa banyak bergantung dengan orang lain.

Alat permainan edukatif busy bag juga dapat mengembangkan aspek lain seperti sosial emosional, kognitif, dan bahasa. Hal tersebut sejalan dengan pernyataan Direktorat PADU, Depdiknas (2003) dalam (Zaman, 2010) menyatakan bahwa alat permainan edukatif sebagai segala sesuatu yang dapat digunakan sebagai sarana atau peralatan untuk bermain yang mengandung nilai edukatif (pendidikan) dan dapat mengembangkan seluruh kemampuan anak.

\section{Simpulan}

Hasil penelitian dan pengembangan ini yaitu produk alat permainan edukatif busy bag untuk motorik halus anak usia 3-4 tahun dengan aspek kemudahan, kemenarikan, dan keamanan. Produk alat permainan edukatif busy bag ini dikembangkan oleh peneliti dengan melalui berbagai proses, dimulai dengan menganalisis kebutuhan hingga proses penyempurnaan sebuah produk yang layak untuk digunakan pada proses pembelajaran motorik halus. Proses penyempurnaan tersebut didapatkan dari saran dan masukan yang diberikan oleh ahli materi dan ahli permainan, serta penggunaan melalui uji coba kelompok kecil. Saran dan masukan yang diberikan oleh para ahli anak usia dini digunakan oleh penulis sebagai pijakan untuk melakukan revisi.

Berdasarkan keseluruhan hasil analisis tinjauan ahli materi dan ahli permainan yang dipaparkan dapat disimpulkan bahwa pada rancangan pengembangan alat permainan edukatif busy bag untuk kemampuan motorik halus anak usia 3-4 tahun telah termasuk dalam kategori sangat valid, namun terdapat beberapa saran guna memaksimalkan produk alat permainan. Hal ini menunjukkan bahwa hasil analisis validasi dari ahli materi dan ahli permainan anak usia dini terhadap alat permainan edukatif busy bag layak digunakan anak untuk kemampuan motorik halusnya. Alat permainan busy bag ini juga dapat mengembangkan rasa percaya diri anak serta melatih kemandirian anak saat bermain tanpa meminta bantuan orang dewasa. Alat 
permainan busy bag ini juga dapat mengembangkan aspek lain seperti aspek kognitif, bahasa, dan sosial emosional.

\section{Daftar Rujukan}

Akbar, S. (2013). Instrumen Perangkat Pembelajaran. Bandung: PT Remaja Rosdakarya.

Decaprio, R. (2013). Aplikasi Teori Pembelajaran Motorik di Sekolah. Jogjakarta: DIVA Press.

Hasyim, A. (2016). Metode Penelitian \& Pengembangan di Sekolah. Yogyakarta: Media Akademi.

Iffah, N. (2018). Pengembangan alat permainan edukatif (APE) untuk meningkatkan keterampilan motorik dan inlegensi anak TK. Lecturer Repository.Ningsih, T. (2018). Pengembangan Alat Permainan Edukatif "kartu baca ngaji asyik" untuk Anak Usia Dini. Yogyakarta: Istana Agency.

Sugiyono, M. P. P., \& Kuantitatif, P. (2009). Kualitatif, dan R\&D, Bandung: Alfabeta. Cet. VII.

Sukmadinata, N. S. (2009). Metode Penelitian Pendidikan. Bandung: PT Remaja Rosdakarya.

Zaman, B. (2010). Pengembangan Alat Permainan Edukatif di Lembaga Pendidikan Anak Usia Dini (PAUD) 